\title{
INTERVENTION OF RIGHT IN CLASS ACTIONS: THE DILEMMA OF FEDERAL RULE OF CIVIL PROCEDURE 24(a)(2)
}

The American Society of Composers, Authors, and Producers (ASCAP) is an unincorporated association of 6400 writers and publishers of musical compositions. The organization takes non-exclusive licenses of the works of its members, licenses these works for public performances, and distributes the revenues to its members.

In 1941 the United States brought an anti-trust action against ASCAP as an entity and as the representative of its members as a class. ${ }^{1}$ One purpose of the suit was to bring about a more democratic administration of the internal affairs of the association and to effect a more equitable distribution of the license revenues. ASCAP and the United States entered into a consent decree. Pursuant to a reservation-of-jurisdiction clause in this decree, the consent judgment was modified in 1950 and again in 1959.

Prior to the adoption of the latest modified decree, the Sam Fox Publishing Company, a small music publisling member of ASCAP, moved to intervene as of riglt in the action. The motion was made pursuant to rule 24(a)(2) of the Federal Rules of Civil Procedure, which permits intervention of right "when the representation of the applicant's interests by existing parties is or may be inadequate and the applicant is or may be bound by the judgment in the action ...." The Fox Company contended that the proposed decree did not go far enough in strengthening the interests of the sinall publishers against the larger concerns who controlled ASCAP by dominating its board of directors. ${ }^{2}$ Fox alleged that he was a member of ASCAP because he had no economic choice but to remain in the

1 ASCAP was charged with a violation of $\S 1$ of the Sherman Act, 26 Stat. 209 (1890), 15 U.S.C. $\$ 1$ (1958). The government's prayer for relief sought to prohibit ASCAP from engaging in certain restrictive practices in dealing with its licensees. It also asked that ASCAP "be prohibited (1) from electing its board of directors other than by a vote of all members for their respective representation; (2) from distributing royalties received to its members except in a 'fair and non-discriminatory manner' based on the 'number, character, and prestige' of the members' compositions, their length of time in ASCAP's catalogue and the 'popularity and vogue of such works' ...." Brief for Appellee, pp. 7-8, Sam Fox Publishing Co. v. United States, 366 U.S. 683 (1961).

2 Fox said it was plain that "the Government had embraced a modification of the 1950 judgment which would surely not achieve a 'democratic administration' of the Society nor even in any substantial way reduce control of the dominating members." Brief for Appellant, p. 40, Sam Fox Publishing Co. v. United States, 366 U.S. 683 (1961). The proposed order reduced the percentage of the total vote that the ten largest publishers held from $63 \%$ to approximately $41 \%$. This reduction, Fox alleged, was not enough to alleviate the situation summarized in the nemorandun that the Department of Justice submitted to the district court in the lower procceding. This memorandum stated:

\footnotetext{
ASCAP's Board of Directors, as hereinbefore stated, has established a distribution system wbich has the effect of favoring certain members at the expense of others, and, at the same time, ASCAP has "weigbted" the votes of its members so as to provide that those members who receive the greatest share of its revenues shall also have the largest number of votes. The vice of this system is that it gives those members in ASCAP who receive the largest share of ASCAP's revenues the power to elect the directors of the Society, who, in turn, have the power to establish the rules governing the Society's system of distribution, which, in turn, determines which members shall receive the largest share of the Society's income.
} 
Society. He contended that he would be bound by any decree issued in the suit, and that since ASCAP's position was dictated by the larger publishers, his interests were not adequately represented.

The district court denied intervention ${ }^{3}$ and Fox appealed directly to the Supreme Court of the United States. Because Fox attempted to intervene as of right, the order denying intervention was an appealable order; ${ }^{4}$ and because the proposed intervention was in a Sherman Act proceeding, the appeal lay directly to the Supreme Court rather than to the court of appeals. ${ }^{5} \mathrm{Mr}$. Justice Harlan, writing for the Court, found that the application to intervene as of right was properly denied and dismissed the appeal.

In applying the "is or may be bound by the judgment" test of rule $24(\mathrm{a})(2)$, Mr. Justice Harlan first concluded that, viewing Fox's proposed intervention as an attempt to align himself with the government, ${ }^{6}$ Fox had no right to intervene because private citizens are not legally bound by the outcome of government litigation though the government is in effect their representative. ${ }^{7}$ Justice Harlan then turned to the question whether Fox could intervene as a defendant with ASCAP. Fox alleged that the directors of ASCAP who negotiated the consent judgment did not adequately represent either the organization as a whole or its smaller members. On the record presented, this allegation was taken as true ${ }^{8}$ so that the Court proceeded on the assumption that Fox had established the inadequacy of ASCAP's representation of his interests. But the Court pointed out that inadequate representation was just one of the two tests for intervention of right under rule 24(a)(2). A potential intervenor had to show also that he would be "bound" by any judgment in the action. This Fox was unable to do.

3 The gist of the district court's opinion was that since Fox was free to enter or withdraw from the Society as a inatter of his own choice, he was precluded from questioning the adequacy of the representation afforded by ASCAP. Mr. Justice Harlan in passing on this argument said, "With respect, we think this begs the question, for appellants' antitrust claim is precisely that, on the one hand, they have no practical choice but to remain in the Society, and, on the other, that the dominance of the large publishers within the Society restricts the competitive opportunities in the industry." Sant Fox Publishing Co. v. United States, 366 U.S. 683,693 (1961).

4 Had Fox attempted to intervene in the court's discretion under Federal Rule 24(b), he supposedly would not have been able to appeal any contrary decision. See, e.g., In re Dolcater, 106 F.2d 30 (2d Cir. 1939). The distinction made under rule 24 that intervention of right decisions are reviewable while discretionary intervention decisions are not is one of the dilemunas posed by the rule as it now stands.

5 Such appeals are allowed in antitrust snits under $\$ 2$ of the Expediting Act, 32 Stat. 823 (1903), as amended, 15 U.S.C. $\$ 29$ (1958).

6 Fox tried to enter the litigation by aligning himself either with the government or with ASCAP. He acknowledged that the Attorney General was advancing the interests of ASCAP's smaller nembers, but felt that in some areas-especially voting rights-the government had not pressed hard enough to rid the Society and the industry of the dominance of the larger publishers.

7 See, e.g., United States v. General Elec. Co., 95 F. Supp. 165 (D.N.J. 1950); Jewell Ridge Coal Corp. v. Local No. 6167 United Mine Workers of America, 3 F.R.D. 251 (W.D.Va. 1943). Mr. Justice Harlan said that because Fox would not be bound by the consent decree, the question of the adequacy of the government's representation did not have to be decided. 366 U.S. at 689.

8 The question was presented-as nitervention questions usually are-on the proposed intervenor's pleading, the allegation of which are taken as true uuless patently frivolous. In light of the prior proceedings, Fox's contention that he was inadequately represented by ASCAP was clearly far from frivolous. 
Mr. Justice Harlan recognized the possibility that, should Fox attempt to further reduce the larger publishers' dominance of the board of directors in a private anti-trust action against ASCAP, any other court would "feel constrained as a matter of comity at least to build on the foundations of the present [consent] decree." However, the Court continued, this "is not at all the equivalent of being legally bound, which is what must be made out before a party may intervene as of right." 10 Legally bound means, in effect, that a decision must be res judicata upon the proposed intervenor's rights in question. ${ }^{11}$ Fox could not show that he would be legally bound by the judgment for, as Justice Harlan pointed out, the Supreme Court in Hansberry $v$. Lee ${ }^{12}$ had held that a judgment in a class action is legally binding on only those members of a class whose interests are adequately represented in the litigation. Fox had shown that he was not adequately represented. Therefore, by the Hansberry rule, he would not be legally bound by any judgment in the action. ${ }^{13}$

The Supreme Court's interpretation of "bound" in Fox coupled with the lolding of the Hansberry case makes rule 24 (a) (2) a nullity, at least in class suits. ${ }^{14}$ As now interpreted, the rule requires that to intervene as of right in a representative suit, one must show both that he is inadequately represented by existing parties and that a judgment will bind him by res judicata. Hansberry showed that these two conditions of rule 24(a) (2) cannot exist at the same time. One is never legally bound by a judgment in a class suit if he is madequately represented in the litigation. ${ }^{15}$

In view of this anomaly, it seems clear that the Federal Rules draftsmen were ill advised to use the word "bound" in rule 24(a) (2) to describe the effect a judgment must have on an inadequately represented intervenor before he may enter an action as of right because "bound" is susceptible of several definitions. It may be defined-as in Fox-in a narrow, res judicata sense, or it may be given a broader definition to take into account the practical out-of-court effect of a judgment as

${ }^{9} 366$ U.S. at 694.

10 Ibid.

11 Stutphen Estates v. United States, 342 U.S. 19 (1951) (Cited in Fox at 688).

12311 U.S. 32 (1940).

13 Although Hansberry deals with a class action, Mr. Justice Harlan seems to apply its principle to all suits involving representation of absent interests. It should also be noted that Fox, in arguing his case, agreed with the government's position that ASCAP was acting in a representative capacity for its nembers.

14 The Fox decision does not affect intervention of right under rule 24(a): "(a) Intervention of right. Upon timely application anyone shall be permitted to intervene in an action: (1) when a statute of the United States confers an unconditional right to intervene . . ..." or under rule $24(\mathrm{a})(3)$, infra note 34.

15 Seemingly less stringent conditions for application of res judieata are required where the representation of a non-party is by one other than a representative of a class. Thus, the Restatement of Judgments states that the disposition of an action in which a trustee, executor, or other like fiduciary represents the non-party beneficiary is binding on the non-party unless the fiduciary is guilty of fraud or collusion. See RESTATEMIENT, JUDGMENTS $\$ \$ 86,91,116-26$ (1942). This would suggest that a non-party putatively represented by a fiduciary is bound by the fiduciary's conduct of the litigation notwithstanding a conflict of interest between fiduciary and beneficiary unless it can be shown that the conflict unatured into actual misunanageinent of the suit. Query whether such a result could be sustained today in hight of Hansberry $v$. Lee. If it could not be sustained, then a non-party represented by a fiduciary would not be hound if inadequately represented, and for the reasons indicated in the text, rule $24(a)$ (2) would be a nullity as applied to intervention in that type of case, as well as in the class suit situation. 
well. It is submitted that the sources used to draft rule $24(\mathrm{a})(2)$ support the latter interpretation of "bound" and point toward a liberal allowance of intervention of right in inadequate representation situations. Such a purpose is frustrated by the Supreme Court's present interpretation of "bound."

To determine the meaning the drafters ${ }^{16}$ attached to the term "bound" and to ascertain the intended scope of the remedy of intervention of right, it is necessary to examine the sources relied upon in developing rule 24 . The notes of the Advisory Committee ${ }^{17}$ say that, in general, the following sources on intervention were examined: (1) existing federal law and equity practice, (2) Admiralty Rules, (3) state codes and procedures, (4) Enghish rules and cases, and (5) an article by James Wm. Moore and Edward H. Levi on federal intervention..$^{18}$ These will be reexamined in order.

The Advisors said that rule 24 "amplifies and restates" the then existing federal practice relating to intervention. Intervention of right in federal procedure found its origin in the Enghish Chancery practice of petitioning pro interesse suo.10 By such a petition, a non-party who claimed a superior right to property under the power of the court was allowed to come into a pending suit and assert his interest. ${ }^{20}$ The federal courts amplified this practice as a means of doing justice in multiple party suits involving property before the court ${ }^{21}$ and of satisfying the diversity requireenent in such suits. ${ }^{22}$ In Freeman $v$. Howe ${ }^{23}$ such an intervention was said to be merely ancillary to the original suit and maintainable without reference to the citizenship of the parties. After Freeman, the federal courts had little difficulty in permitting intervention of right without an independent basis of jurisdiction when the potential intervenor clained an interest in property actually before the court. ${ }^{24}$ Intervention became an increasingly popular means of affording interested third parties rehef from the potential impact of federal decisions. In 1925, however, the Supreme Court warned the lower courts that no controversy was ancillary unless it had a direct relation to property or assets actually or constructively drawn into the court's possession. ${ }^{2 \overline{5}}$

16 In June of 1934, Congress gave the Supreme Court the power to prescribe federal rules of procedure. Approximately one year later, a distinguished Advisory Committee was appointed to draw up proposed rules. The final rules were approved by the Supreme Court and became effective in September of 1938. Hart \& Wecrsler, The Federat, CourTs aNd THE FEDERAL SYSTEM 588-89 (1953).

17 Fed. R. Crv. P. 24.

18 Moore \& Levi, Federal Intervention, 45 Y ALE L.J. 565 (1936).

192 Street, Federac Equity Practice 830 (1909). Pro interesse stoo translated means "to the extent of his interest."

201 Simte, Chancery Practice 451, 452 (2d ed. 1842).

21 Pennock v. Coe, 64 U.S. (23 How.) 117 (1859).

22 Freeman v. Howe, 65 U.S. (24 How.) 450 (1860).

23 Ibid.

24 Perlman v. United States, 247 U.S. 7 (1918) (property impounded for a forthcoming prosecution); Krippendorf v. Hyde, 110 U.S. 276 (1884) (attached property); French v. Gapen, 105 U.S. 509 (1881) (foreclosed property).

25 Fulton Bank v. Hosier, 267 U.S. 276 (1925); see Campbell, Jurisdiction and Venute Aspects of Intervention Under Federal Rule 24, 7 U. PIrT. L. REv. 1, 6, 7 (1940). It is interesting to note that the scope of intervention of right was expressly delineated in 1900 by the Supreme Court in Credits Commutation Co. v. United States, 177 U.S. 311 (1900). In accepting a lower court's opinion, the Court said that the only cases where intervention of right is allowed ". . are those where there is a fund in court undergoing administration to which a third party asserts some right which will be lost in the event that he is not allowed to intervene before the fund is dissipated." Id. at 316. 
Until 1912 no federal rule expressly provided for intervention, either by right or in the discretion of the court. ${ }^{26}$ In that year, the Supreme Court undertook a comprehensive revision of its equity rules and in so doing adopted a provision for intervention, Equity Rule $37 .{ }^{27}$ This rule couched the requirement for intervention in terms of an "interest in the litigation." The word "interest" received varying interpretations from the federal courts applying Equity Rule $37 .{ }^{28}$ It was said that wliere the person seeking to intervene had a "direct" and "immediate interest" in property that was the subject of the suit, he could intervene as of right. ${ }^{29} \mathrm{Pre}-$ sumably, however, where the petitioner had a lesser interest-one not involving property before the court or one that was "indirect" or remote-only discretionary intervention was available.

Cases under the Admiralty Rules ${ }^{30}$ furnished precedents similar to those just described. If a person asserted an interest in the proceeds of a fund under the control of an admiralty court, he was entitled to intervene as of right. ${ }^{31}$ Thus, in the mid-thirties when the Advisory Committee drafted the federal rules, there existed in the federal courts a somewhat nebulous area of discretionary intervention $^{32}$ and a supposedly settled area of intervention of right confined to cases where there was property in control of the court. ${ }^{33}$ Accordingly, it would seem that the then existing federal and admiralty precedents gave the draftsmen definite aid only in the task of drafting a rule dealing with intervention of right in pro interesse suo cases. $^{34}$

It should be noted that the judgments in cases involving dispositions of property were not res judicata for an unrepresented absentee. The decree in such a case cut off no rights or remedies. ${ }^{35}$ Intervention was allowed on the theory, not that the rights of an interested petitioner would be legally precluded, but rather that they would be jeopardized, in a practical sense, by a dissipation of the fund or assets under the court's control. ${ }^{36}$ Therefore, these pro interesse suo cases could not have provided any precedent for a narrow, res judicata meaning of bound in rule 24(a) (2), nor could they have provided any basis for a meaning of the word in any context apart froin a dissipation-of-funds problem.

Existing state codes furnished a wealth of case material on intervention but very little in the way of a cogent analysis of the underlying problems. It has been said that the states afforded "procedural laboratories" for examining intervention practices. ${ }^{37}$ Many liberal views of intervention were available in the state "labor-

${ }^{26}$ There was no mention of intervention in the Federal Equity Rules of either 1822 or 1842 .

27 Equity R. 37, 226 U.S. 659 (1912).

28 See, e.g., United States v. Houde Eng'r Corp., 9 F. Supp. 836 (W.D.N.Y. 1935) ; Universal Oil Prods. Co. v. Standard Oil Co., 6 F. Supp. 37 (W.D. Mo. 1934).

20 United States v. California Co-op. Canneries, 279 U.S. 553, 556 (1929).

30 Federal AdDTRaLty Rules $34 \& 42$.

31 See, e.g., The Charles D. Leffler, 100 F.2d 759 (3d Cir. 1938).

32 Intervention in the court's discretion called for a balancing of many factors and as such its standards were incapable of precise definition.

33 See Slupsky v. Westinghouse Elec. \& Mfg. Co., 78 F.2d 13 (8th Cir. 1935).

34 The result of work in this area was FED. R. Civ. P. 24 (a) (3) which as initially drafted in 1938 reads: "Intervention of Right. Upon timely apphication anyone shall be permitted to intervene in an action ... (3) when the applicant is so situated as to be adversely affected by a distribution or other disposition of property in the custody of the court or an officer thereof."

35 See, e.g., Rhinehart v. Victor Talking Macl. Co., 261 Fed. 646 (D.N.J. 1917).

36 Moore \& Levi, Federal Intervention, 45 YaLE L.J. 565, 582 (1936).

37 Id. at 574. 
atories,"38 but in general, state decisions followed federal practice and allowed intervention of right only in situations in which there was property in control of the court. ${ }^{39}$

The English practice on intervention of right was regulated by rules and decisions embracing specific situations rather than by rules of general application..$^{40}$ The Federal Rules Advisory Committee, insofar as they referred to English practice, placed principal rehance on the liberal case of Wilson v. Church ${ }^{41}$ as an example of intervention of riglt in representative actions. In Wilson, a bondholder sued his debtor corporation on behalf of himself and all other bondholders. He attempted to claim for the bondholders a certain fund in the hands of the corporation. A fellow bondholder appeared, took an opposite view, and sought to come into the suit to represent his own interests. Sir Jessel, Master of the Rolls, allowed the intervention saying:

He has an interest ... as an individual. He says in effect, "My rights will be affected," and they certainly will, "if judgment is given in favour of the plaintiffs, and I insist that I should be here to dispute the contentions of the plaintiffs." I think it is too plain for argument. He not only has an interest, but a substantial interest . . . the right course is to add him . . . as a defendant. 42

The rule of Wilson reduced to its simplest terms allowed a member of a class to intervene by stepping forward and saying, "The Plaintiff does not represent me. Add me as a defendant." 43

Representative actions had been known in England since at least as early as $1722.4^{44}$ By the time of Wilson, it was settled that the interests of an absentee could be decided in a class action if such interests were fairly represented. ${ }^{4 \sigma}$ The

38 See, e.g., Grand Lodge v. Grand Lodge, 86 Colo. 33, 282 Pac. 193 (1929); Morey v. Lett, 18 Colo. 128, 31 Pac. 857 (1892); see also, Pomerox, REMEdIES AND REMEdias RuGHis $\S 411$ (2d. ed. 1883).

39 See, e.g., Crowe v. Hamilton Nat'1 Bank, 74 Colo. 407, 222 Pac. 394 (1924); Walpole v. Rogers, 66 Colo. 583, 185 Pac. 346 (1919); State v. Farmers' Bank, 103 Neb. 194, 170 N.W. 901 (1919) ; Ladd v. Sevenson, 112 N.Y. 325, 19 N.E. 842 (1899).

40 English Rules gave an absolute right to intervene in certain admiralty, land, probate, execution, and divorce actions. Notes of the Advisory Committee, FED. R. Crv. P. 24, 28 U.S.C. App. (1952).

41 [1878] 9 Ch. D. 552.

42 No authority was cited for this rather inatter-of-fact allowance of intervention, but Master Jessel's position was not entirely new in English law. In Cockburn v. Thompson, 16 Ves. Jun. 321, 327-28, 33 Ch. 1005, 1007-08 (1809), it was said:

In the familiar case of creditors, suing on behalf of themselves and all others, what infinite number of valuable interests may be bound, in a sense, not absolutely; as, where the Court for convenience dispenses with the presence of parties, the principle leads it by future arrangement to find out the means of giving them an opportunity in some shape of coming in .... and I should upon principle find the means, if not supplied by precedent, of giving a creditor, coming in after the institution of a suit, the opportunity of supporting his interest better than tlie plaintiff could.

See also Mozley v. Alston, $1 \mathrm{Ph} .790,41 \mathrm{Ch} .833$ (1847); Calvert, Equitr 58 (1837). It should also be observed that the creditor's suit again involves claims to a fund before, or sought to be brought before, the court.

43 McCheane v. Gayles, (no. 1) [1902] 1 Ch. 911, 915.

44 See Chancey v. May, Prec. Ch. 592, 24 Ch. 265 (1722).

46 See, e.g., Commissioners of Sewers of the City of London v. Gellately, [1876] $3 \mathrm{Ch} . \mathrm{D}$. 610 (decided by Master Jessel two years before he decided Wilson v. Church); Smith v. Brownlow, [1870] I.R. 9 Eq. 241; Mayor of York v. Pilkington, 1 Atk. 282, 26 Cl. 180 (1737); ADAMS, EQUITY 715-17 (1815). 
reciprocal of this proposition-that the rights of a person with an interest could not be affected unless such a person was adequately represented-had also been stated in English courts. ${ }^{46}$ The court in Wilson made no reference, however, to this latter principle and made no attempt to reconcile the principle with its holding that the proposed intervenor should be allowed to intervene because his "rights will be affected." on the vague reference to the intervenor's interest in the litigation. In this light, Wilson v. Church, though advocating a liberal allowance of intervention of right, was certainly skimpy authority for a definitive statement of the basis of the intervention remedy.

Moore and Levi's article on the history of federal intervention was a comprehensive work with a liberal tone. The writers felt that an absolute right to intervene was sometimes essential to protect the interests of third parties. ${ }^{48}$ They traced the development of intervention of right both where property was in control of the courts ${ }^{40}$ and where a person was inadequately represented in an existing litigation..$^{50}$ To show that one had an absolute right to intervene when he was inadequately represented in a suit and bound by its decision, Moore and Levi drew largely on cases of reorganization and receivership where classes of bondholders, stockholders, and unsecured creditors were represented by a selected few of their respective members. ${ }^{.1}$ The typical pattern in these cases was that the members of the class elected or approved representatives designated to appear for the class. Theoretically such authorization would constitute a continuing recognition of the adequacy of the representation that followed. In fact, however, within the class represented there sometimes developed factions or at least sharp differences of opinion on litigating strategy. ${ }^{52}$ It could hardly be said that the representation continued to be truly adequate in such cases. Moore and Levi, rightly it would seem, thought that the dissidents should have some remedy by which to assert their position, and they thought that the remedy should be available as of right and not merely in the discretion of the court..$^{53}$ This position was

46 See Shepherd v. Towgood, Turn. \& R., 379, 391-92, 37 Ch. 347, 1151-52 (1823); May v. Newton, [1887] $34 \mathrm{Ch} .347$ (decided after Wilson).

47 The difficulty of reconciling these two positions was, of course, the precise problem presented in Fox.

48 Moore \& Levi, Federal Intervention, 45 Yare L.J. 565, 607 (1936).

49 As suggested previously, the property-before-the-court cases do not support the thesis that intervention is to be allowed because the intervenor will be bound (in the res judicata sense) by the result of the litigation. See text supra at note 35 .

50 The pro interesse suo type of absolute intervention was comprehsensively traced. With intervention of right based on inadequate representation, however, the authors seem to have done a less thorough job. Only one case was cited to substantiate Moore and Levi's view that an absolute riglit to intervene existed when a petitioner was inadequately represented and would be bound by a judgment. This was a sphit appellate decision that rehed heavily on a pro interesse suo case for authority. Central Trust Co. v. Chicago R.I. \& P.R.R., 218 Fed. 336 (2d Cir. 1914). Moore \& Levi, supra note 48 at 581.

51 Moore \& Levi, supra note 48 at 592.

52 See, e.g., Fearon v. Bankers' Trust Co., 238 Fed. 83 (3d Cir. 1916) (showing how holders of the same issue of bonds can sphit into conflicting groups); Farmers' Loan \& Trust Co. v. Cape Fear \& Y. V. Ry., 11 Fed. 38 (C.C.E.D.N.C. 1895); Farmers' Loan \& Trust Co. v. Northern Pac. R.R., 66 Fed. 169 (C.C.E.D. Wis. 1895).

53 Moore \& Levi, Federal Intervention, 45 YaLE L.J. 565, 595 (1936). Moore and Levi were primarily interested in allowing minority interests to intervene in reorganization proceedings at the earliest possible time. They felt that those wbose interests were before the court should be able to protect these interests before any reorganization plan was even begun. Id. at 599-604. 
substantiated in some lower federal decisions, ${ }^{54}$ but it was by no means a settled rule of law. ${ }^{55}$

Reorganizations were like simple pro interesse suo cases in that they both involved conflicting claims to funds or assets in control of the court. ${ }^{50}$ As to intervention, however, the two groups of cases differed. A potential intervenor in a reorganization or a receivership had to overcome the contention that, because of the presence of a representative, his interests were already represented before the court. The problems of representation and its adequacy were examined by the courts, ${ }^{57}$ and it was usually held, contrary to simple pro interesse suo cases, that intervention in a reorganization or receivership was discretionary and within the "sound legal judgment" of the courts. ${ }^{58}$ Moreover, the issue in these cases was not, or at least not clearly, the question whether the proposed reorganization plan would be res judicata; rather, the issue was whether the disposition of the assets involved would be unfair. This seems precisely analagous to the dissipation problem found in cases of the pro interesse suo type, a problein covered effectively by rule 24 (a) (3)..$^{59}$ Hence, given this rule, the question remained whether any separate rule, such as rule 24(a)(2), could be drafted on the strength of the reorganization cases.

It would appear that reorganization cases offered little support for such a separate rule. These cases had not squarely faced the question of the relation between adequacy of representation and res judicata. ${ }^{\circ 0}$ Because of the consensual or contractual nature of the selection of a representative in a reorganization, ${ }^{61}$ it was generally found (short of flagrant misconduct) that a party was held to his representative's actions. ${ }^{62}$ In addition, an absentee was usually bound in a

54 See, e.g., Central Trust Co. v. Chicago R. I. \& P. R.R., 218 Fed. 336 (2d Cir. 1914); Farmers' Loan \& Trust Co. v. Cape Fear \& Y.V. R.R., 71 Fed. 38 (C.C.E.D.N.C. 1895); Farmers' Loan \& Trust Co. v. Northern Pac. R.R., 66 Fed. 169 (C.C.E.D. Wis. 1895).

${ }^{55}$ See Guarantee Trust Co. v. Chicago M. \& St. P. Ry., 15 F.2d 434 (N.D.Ill. 1926); Palmer v. Bankers' Trust Co., 12 F.2d 747 (8th Cir. 1926) ; Continental \& Commercial Trust \& Sav. Bank v. Allis-Chalmers Co., 200 Fed. 600 (E.D.Wis. 1912). See also quotation in note 25 supra.

${ }^{56}$ In a reorganization or a receivership there is actually no property before the court, yet the court does control the rights to the assets in question and can effectively dispose of or alter these rights.

${ }^{57}$ See, e.g., Continental \& Commercial Trust \& Sav. Bank v. Allis-Chalmers, 200 Fed. 600 (E.D.Wis. 1912).

68 See note 55 supra.

59 See note 34 supra.

60 The precise problem of the effect a judgment bad to have on an inadequately represented absentee before his petition to intervene of right would be granted bad not been conclusively solved. It seems, however, that in the reorganization cases listed by Moore and Levi and studied by the Advisory Committee any solution calling for a test with res judicata connotations would not have appeared at the time to present an insurmountable hurdle. The penetrating analysis of Hansberry was not available in 1936. The formula of rule 24(a) (2) must have been thought of by the drafters as one that would provide for two distinct tests for intervention of right. Hansberry, however, shows that the two tests can not exist together if "bound" is to have a res judicata definition. It seems obvious that had the drafters anticipated the Hansberry result, they would not have drafted the rule as they did.

61 Bondholders who exchange their bonds for certificates of deposit in reorganizations involving protective committees definitcly appoint the heads of these committees to represent them. Rodgers, Rights and Duties of the Committee in Bondholders Reorganizations, 42 HARV. L. REv. 899, 900 (1929).

62 See, e.g., Richter v. Jerome, 123 U.S. 233 (1887); Guaranty Trust Co. v. Chicago M. \& St. P. Ry., 15 F.2d 434 (N.D.Ill. 1926) ; Hartford-Connecticut Trust Co. v. Doherty, 286 Fed. 926 (6th Cir. 1923); see also note 15 supra. 
practical sense by the final reorganization scheme. Courts were reluctant to overturn reorganization plans because they were generally the product of many months' work ${ }^{63}$ and because they invariably had the backing of a majority of the interests involved. ${ }^{64}$ This being true, a petitioning intervenor in a reorganization could readily argue that he would be bound by the reorganization decree without having to state with care what was meant by "bound." Further, the courts could rule on a petition to intervene in a reorganization with similar indifference to the precise sense in which the term was being used. This left unresolved and perhaps unperceived the ambiguity of the word "bound" when applied to other types of representative suits in which the adequacy of representation was drawn in question. ${ }^{65}$ Hence, it is difficult to find any clear support in precedent for a rule formulated in the terms set forth in rule 24(a) (2).

It seems fair to conclude that Moore and Levi wanted to allow intervention of right in certain situations where an absentee claimed to be inadequately represented, but that they were able to construct only a thin line of precedent to confirm their view. As pointed out previously, federal, admiralty, and state intervention of right cases dealt with pro interesse suo situations, which did not involve the principle that a judgment had to be res judicata against a potential intervenor. Moreover, these cases did not involve questions of representation. Accordingly, the only authority for the formula adopted in rule 24(a)(2) would seem to be Wilson v. Church and the Moore and Levi article. In view of the casual nature of the court's analysis in Wilson and the limited base of authority supporting the Moore and Levi thesis, it seems clear that there was hittle warrant for the sweeping generalization attempted in rule 24(a)(2). In light of Hansberry v. Lee, it is evident that the formula of the rule is not only too broad ${ }^{86}$ but, as Fox slows, self-contradictory if "bound" means bound by res judicata.

The difficulty with the formula of rule $24(\mathrm{a})(2)$ appears more clearly when it is contrasted with other grounds for intervention provided for in rule 24. Rule 24(a) (3) allows intervention of right when "the applicant is so situated as to be adversely affected by a distribution or other disposition of property which is in the custody or subject to the control or disposition of the court. ..." This refers to interventions of the pro interesse suo type, which, as noted above, was

63 See, e.g., Fearon v. Bankers' Trust Co., 238 Fed. 83 (3d Cir. 1916).

64 See, e.g., Jameson v. Guaranty Trust Co., 20 F.2d 808 (7th Cir. 1927); Duncan v. Mobile \& O. R.R., 8 Fed. Cases 25 (1879).

05 Those few non-receivership cases acknowledging that the remedy of intervention of right did exist for an inadequately represented absentee offered little discussion of the effect a judgment had to have on his rights before intervention would lie. These cases did not conclusively establish whether a forthcoming judgment had to bind one in a legal or a practical sense before he could intervene as of right. Compare Slupsky v. Westinghouse Elec. \& Mfg. Co., 78 F.2d 13 (8th Cir. 1935), with McKee v. Brazell, 284 Fed. 554 (8th Cir. 1922). In Slupsky, the court stated that intervention may be of right "where the petitioner, not being fairly represented in the hitigation, is asserting a right which could be lost or substantially affected if it could not be asserted at that time and in that form . ..." (Emphasis added.) McKee, however, took the view that one did not have an absolute right to intervene if his legal rights would not be impaired in a legal sense by a denial of the request to intervene.

${ }^{66}$ The ambiguous "bound" has proven incapable of providing constant, meaningful criteria for the solution of intervention problems. See Kozak v. Wells, 278 F.2d 104, 110 (8th Cir. 1960). Compare Cameron v. President Fellows of Harvard College, 157 F.2d 993 (1st Cir. 1946) and Owen v. Paramount Prods., 41 F. Supp. 557 (S.D. Cal. 1941), with Clark v. Sandusky, 205 F.2d 915 (7th Cir. 1953) and United States v. C. M. Lane Lifeboat Co., 25 F. Supp. 410 (E.D.N.Y. 1938). 
the only case of intervention of right solidly established in the precedents prior to the Federal Rules. ${ }^{67}$ Rule 24(b) deals with discretionary intervention, also solidly established in the precedents. ${ }^{68}$ The question posed by rule $24(\mathrm{a})(2)$ therefore is whether there is a type of situation (1) which does not involve "property ... subject to the control ... of the court," (2) in which intervention should be allowed of right and not merely in the court's discretion, and (3) which can be designated by a meaningful legislative formulation. Fox shows that it is not meaningful to speak in terms of the res judicata effect of the potential decree. Is there, then, some way of describing cases where intervention should be of right though the decree will not be res judicata and that does not involve precisely the balancing of the sanie considerations that go into discretionary intervention? Resolving this question requires closer inquiry into the ways that a determination may "affect" the "interests" of the absentee.

It seems that a determination may affect unrepresented interests in one or more of the following ways:

(1) It will result in a precedent that will by operation of the rules of stare decisis dispose of the claims of the absentee. Obviously, intervention at the trial stage by all absentees who might be so affected would be intolerable. Theoretically, any case could result in a disposition having stare decisis value. ${ }^{09}$ Furthermore, as a practical matter, it would be difficult: to state a rule that would meaningfully differentiate between cases likely to have important stare decisis consequences and those unlikely to do so. It might be possible, however, to single out the test case as one in which intervention of right should be allowed. A test case can be defined as one in which the nature of the issues framed by the pleadings and the apparent scope of the proposed proof disclose that the main object of the litigation is to obtain an authoritative ruling on a question of general inter-

67 See note 25 supra. Rule 24(a) (1) is but an incorporation by reference of ad hoc intervention rules and does not purport to generalize about intervention.

68 See, e.g., Rodman v. Richfield Oil Co., 66 F.2d 244 (9th Cir. 1933); O'Connell v. Pacific Gas \& Elec. Co., 19 F.2d 460 (9th Cir. 1927); Palmer v. Bankers' Trust Co., 12 F.2d 747 (8th Cir. 1926).

60 Many people can validly claim that a judgment will affect their interests. Yet, it is the nature and extent of this effect, not merely its presence, that must be examined when such persons desire to intervene as of right. When a forthcoming judgment will have a substantial effect on the rights-either legal or practical-of an inadequately represented absentee, it seems he should be able to enter a suit as of riglit. In such a case a petitioner should not be barred by any contentions that efficient judicial administration requires a limited number of parties or that an existing litigant should be able to control the scope of his own suit.

The arguments against interpreting "bound" in the present rule 24(a) (2) in any other than a res judicata sense were ably advanced in a Note in 63 YALE L.J. 408 (1954). The writer there stated that a liberal interpretation of "bound" was undesirable because the resulting expansion of intervention of right would bring about a contraction of permissive intervention. Such a reduction of the scope of permissive intervention would, it was argued, curtail the trial judge's power to take into account the particular positions of all the parties to a litigation when passing on an intervention petition. The author also felt that a widening of rule 24(a) (2) would not only tempt many unsuccessful applicants to appeal and thereby further burden already crowded federal dockets, but would also prejudice existing parties by forcing them to accept the interjection of new parties and issues into their suits.

It is certainly arguable that the writer's unain argument places too much confidence in the non-reviewable, discretion of trial judges. It is also interesting to note that Moore and Levi dismissed the other arguments advanced. 45 YaIE L.J. 565, 606. They felt that appellate courts liad already been examining the inerits of most intervention petitions and that any fear of suits being overwhelmed with new parties was groundless. 
est. ${ }^{70}$ Beyond such cases, however, it would seem that intervention should be only a matter of discretion, calling for a balancing on the one hand of the litigants' interests in obtaining a resolution of their controversy unencumbered by the presence of other parties and other issues, and on the other of the absentee's interest in seeing that the questions of interest to him are effectively presented. ${ }^{71}$

(2) It will sanction or order a course of conduct affecting an existing situation that the proceedings are chiefly intended to stabilize, which involves the absentee's out-of-court affairs in a significant way, and to which the absentee has a relationship significantly different in point of practical interest from any of the litigants. This seems to be the real underlying rationale for intervention pro interesse suo, and there seems no reason why that rationale should not have general applicability. It may be observed that the ASCAP proceedings were intended to have the stabilizing effect referred to above and that the value of such stability was apparently what Mr. Justice Harlan had in mind when he suggested that the proceedings in which Fox sought to intervene would be accorded "comity" by another court. Judged by these criteria $F o x$ was wrongly decided, but again it would seem that rule 24 (a) (2) did not helpfully pose the real issue to be decided.

(3) It will result in saddling the defendant with an additional claim that will render him less able to pay the absentee's claim. In it simplest form, this is the situation presented where a creditor sues a distressed debtor who has debts outstanding to others. At common law, the absent creditor had no right to resist this. ${ }^{72}$ Under modern law, his ultimate means of resistance is not intervention but separate bankruptcy proceedings, so that an intervention rule is unnecessary to cover this situation.

(4) It will result in a redefinition of interests in specific property, interests that may have to be set aside or subordinated if the absentee is to establish the priority of his claim to the property. This is covered by rule 24 (a) (3).

(5) It will result in a dispersion of a fund to which the absentee must look if his claim is to be satisfied. This is also covered by rule 24(a)(3).

(6) It will be res judicata as to the absentee if he is found to be adequately represented. This result could arise either in a class suit or in a suit to which a fiduciary is a party. It would appear that this is the type of situation at which the present rule $24(\mathrm{a})(2)$ was aimed. The crucial procedural question in this situation is whether the absentee should be permitted to challenge the adequacy of his representation before judgment, during the hearing on an intervention petition, or after judgment, by collateral attack. Fox suggests the latter rule, but the unfortunate phraseology of the present rule $24(\mathrm{a})(2)$ has obscured the real question. It would appear that an absentee should be allowed to intervene as of right when (1) there is someone before th; court purporting to represent him, (2) the absentee makes a showing that there is a reasonable basis to suppose that the proposed representation may not be adequate, and (3) the burden of a collateral attack will be unreasonably onerous as a practical matter when compared with proceeding by intervention. There seems no obstacle to redraft-

70 No provision is presently made for intervention in this situation by either the Federal Rules or commonly encountered state rules. $C f$. the government's statutory right to intervene in constitutional cases. 28 U.S.C. $\$ 2403$ (1948).

71 It should be noted that, in lieu of intervention, the role of an amicus curiae is open to an interested non-party. An excellent discussion of the amicus curiae procedure is found in Covey, Amiculs Curiae: Friend of the Court, 9 DE PAUL L. REv. 30 (1959).

72 See Henderson, ReMTINGTON ON BANRRUPTCY \$ 3 (5th ed. 1950). 
ing rule 24(a) (2) along these lines. Judged by these criteria, it would seem that Fox was wrongly decided.

It is difficult to conceive of other ways in which a determination in a particular case could be of such interest to a non-party that it would be a proper occasion for intervention. Each of the foregoing situations requires the exercise of trial court judgment; indeed it seems impossible to formulate an intelligible rule regarding intervention that does not call for the exercise of such judgment. Hence, it seems doubtful that any rule of intervention can be drawn which is not discretionary in this sense, and therefore equally doubtful that a meaningful distinction can be drawn between intervention of right and discretionary intervention, as is attempted by the existing rule 24 . The most that can be done is to differentiate between discretion and its abuse. ${ }^{73}$

The principal consequence under present law of the supposed distinction between intervention of right and discretionary intervention is that the denial of a motion to intervene of right is appealable, while denial of a motion to intervene in the court's discretion is not. ${ }^{74}$ The cases deciding appealability under the present rule 24 seein irreconcilable. ${ }^{75}$ It seems reasonable to say that the appellate courts in deciding the appeal issue are in reality determining whether the intervention should have been allowed and then classifying the motion as one under rule 24(a) (2) (of right, therefore appealable) or under rule 24(b) (discretionary, therefore not appealable). The narrow scope of $F o x$ will make such manipulation difficult and the underlying problems of rule 24 will no doubt be brought out in full confrontation. This will require a reconstruction of the rule and a correlative reappraisal of the problem of appealability.

It is suggested that a sufficient number of cases have arisen since 1938 that a comprehensive study of intervention in inadequate representation situations, based on experience the early drafters lacked, can now be undertaken. The remedy of intervention of right is too important to be restricted as it is today by a narrow definition of the ambiguous term "bound." Rule 24 should be redrafted" to bring it into line with the liberal import of its sources and to make it conform with the expressions of hiberality toward third party practice found in modern cases. ${ }^{77}$

Jolin W. Stack

${ }^{73}$ Cf. indispensible party practice. E.g., Calcote v. Texas Pacific Coal \& Oil Co., 157 F.2d 216 (5th Cir. 1946).

74 Discretionary intervention under the present rule $24(\mathrm{~b})$ is non-reviewable. Sec Textile Workers Union of America v. Allendale Co., 226 F.2d 765 (D.C. Cir. 1955); Thompson v. Broadfoot, 165 F.2d 744 (2d Cir. 1948).

75 Compare Textile Workers Union of America v. Allendale Co., 226 F.2d 765 (D.C. Cir. 1955), with Cresta Blanca Wine Co. v. Eastern Wine Corp., 143 F.2d 1012 (2d Cir. 1944).

76 The writer does not expressly suggest what the rule in this area should be. Two possible revisions of rule 24 , however, seem plausible. A vague "interest in the hitigation" test, wherein any distinction between intervention of right and discretionary intervention is removed, could be adopted provided all such intervention decisions were made reviewable. Such a rule would provide for a flexible, case by case solution of intervention problems and at the same time, safeguard a petitioner's interests via the appellate process. In contrast to a vague rule, a solution such as that proposed in New York for a problem closely related to interventionnamely, necessary joinder of parties-could be adopted. The Advisory Committee on Practice and Procedure for New York has chosen to specifically enumerate certain conditions a court must examine in passing on joinder problems. The type of tests laid down in the proposed rule would seem appropriate to the solution of intervention problems. See the Prectmmnary Report of xhe Advisory Committee on Practice and Procedure for the State of New YoRr tit. 23.1, at 28 (1957).

${ }^{77}$ See Kozak v. Wells, 278 F.2d 104, 111 (8th Cir. 1960). 